\title{
Detection of group B streptococcal antigen in necropsy specimens using monoclonal antibody and immunoperoxidase staining
}

\author{
RG FELDMAN,* SM LAW, $†$ JR SALISBURY† \\ From the Departments of *Clinical Microbiology and $\dagger$ Histopathology, University College Hospital, London.
}

SUMmARY A murine monoclonal antibody, which recognises various serotypes of group B Streptococcus in formalin fixed, paraffin embedded tissue, was used to show the organism in necropsy specimens of newborn infant lung by an indirect immunoperoxidase technique. The method seemed to be complementary to that of Gram staining, and may be successfully used to identify group B Streptococcus antigen in histopathological material.

Group B Streptococcus is a common cause of bacterial sepsis in newborn infants. Disease of early onset, which occurs in the first week of life, produces high mortality, especially if treatment is delayed. ${ }^{1}$ Although the clinical presentation is often nonspecific, a microbiological diagnosis may be made, usually without difficulty, by culturing blood, cerebrospinal fluid, urine, and tracheal aspirate. More recently, several rapid methods for detecting antigens, including latex agglutination and coagglutination, have become available. ${ }^{23}$ Nevertheless, some undiagnosed necropsy specimens such as lung tissue, showing evidence of pneumonia, may be due to group B Streptococcus.

We describe an indirect immunoperoxidase staining technique for use on tissue, infected with group B Streptococcus, using both monoclonal and polyclonal antibody preparations.

\section{Material and methods}

\section{ANTI-GROUP B STREPTOCOCCUS MONOCLONAL} ANTIBODY

A monoclonal antibody reactive with all types of group B Streptococcus was prepared using a method similar to that described by Ruch and Smith. ${ }^{4} \mathrm{~A}$ BALB/c mouse was immunised with a $0.3 \mathrm{ml}$ suspension of $0.3 \%$ formalinised group B Streptococcus strain 090R (NCTC 11360), prepared as described by Lancefield, ${ }^{5}$ and injected intraperitoneally. After

Accepted for publication 2 October 1985 seven weeks a single intravenous boost was given three days before the spleen was removed for hybridisation.

Fusion of spleen cells with NS1 plasmacytoma cells was based on the Kohler and Milstein technique. ${ }^{6}$ One millilitre of $50 \%$ polyethylene glycol (Sigma) was added to a pellet of combined spleen and NS1 cells for one minute, mixed for one minute, and then $2 \mathrm{ml}$ of Roswell Park Medical Institute 1640 medium (Flow Laboratories) was added over a period of two minutes. After washing the cells were suspended in medium containing $10 \%$ fetal calf serum, hypoxanthine, aminopterin, and thymidine. A series of $2 \mathrm{ml}$ wells were filled using a suspension of $5 \times 10^{4}$ cells/well. These were screened for antibody to group B Streptococcus on day 16, using the indirect agglutination technique described below. Wells positive for antibody were cloned twice by limiting dilution, once at 10 cells/well and then at a dilution averaging one cell/three wells, after which all supernatants contained anti-group B Streptococcus antibody. Supernatant collected after five days of cell growth was used for further screening against previously typed clinical isolates of various serotypes of group B Streptococcus (Ia, Ib, Ibc, II/R, and III); streptococci belonging to groups A, D, and G; Streptococcus pneumoniae, Staphylococcus aureus, Pseudomonas aeruginosa, and Escherichia coli. One antibody was found to react with the representative group B Streptococcus serotypes (but not with any of the other organisms tested), by using the immunoperoxidase method on a cytospin preparation of whole formalinised bacteria. 
INDIRECT AGGLUTINATION TECHNIQUE

This method was developed to detect antibody to group B Streptococcus for use as a rapid screening method in the preparation of the described monoclonal antibody.

Twenty $\mu \mathrm{l}$ of phosphate buffered saline (pH 7.4) was mixed with $10 \mu \mathrm{l}$ of the test supernatant in a U shaped microtitre well. Subsequently $30 \mu 1$ of a suspension of group B Streptococcus killed in 3\% formaldehyde was added. After five minutes of incubation at room temperature $30 \mu 1$ of a $1 / 100$ dilution of goat antimouse IgG serum (Miles Scientific) was added to the well and incubated for 10 minutes at room temperature. All dilutions were made with phosphate buffered saline. The well was then centrifuged at $1000 \mathrm{rpm}$ at $4^{\circ} \mathrm{C}$ for five minutes. Agglutination of the group B Streptococcus was indicative of the presence of anti-group B Streptococcus IgG. Positive screening tests were confirmed by immunofluorescence. $^{7}$

\section{POLYCLONAL SERUM}

Commercially available group B Streptococcus antiserum raised in rabbit was used (Streptococcus grouping serum group B, Wellcome Diagnostics).

\section{LUNG TISSUE}

Lung tissue was removed at necropsy from three newborn infants who had died as a result of overwhelming group B Streptococcus septicaemia and pneumonia within 48 hours of birth. In each case the organism had been isolated from blood cultures before death.

Lung tissue was also removed from three newborn infants known to have died from microbial causes other than group B Streptococcus for control purposes. The three organisms were Listeria monocytogenes and Staphylococcus aureus, both associated with pneumonia, and Pseudomonas aeruginosa, the cause of a septicaemia in this infant.

\section{IMMUNOPEROXIDASE STAINING}

Sections (4 $\mu \mathrm{m}$ thick) of formalin fixed and paraffin embedded lung were stained by the indirect immunoperoxidase technique ${ }^{8}$ with the anti-group B Streptococcus monoclonal antibody. Staining was optimal at a dilution of 1 in 10 and at an incubation time of one hour. Serial sections of lung were also stained with the polyclonal antibody by the peroxidaseantiperoxidase (PAP) technique. ${ }^{9}$ The staining with this antibody was optimal at a dilution of 1 in 100 and an incubation time of $\mathbf{3 0}$ minutes.

Endogenous peroxidase was inhibited in all sections using $0.5 \%$ hydrogen peroxide in methanol for 10 minutes. Control sections of lung in which Tris buffered saline and non-immune serum replaced the primary antibody were run in parallel with the other immunoperoxidase slides. All immunoperoxidase sections were counterstained with Mayer's haematoxylin.

In addition, sections of the lung were stained with haematoxylin and eosin and Gram's stain for comparison.

\section{Results}

Light microscopy of all three lung sections showed the presence of pneumonia; in two cases this was patchy. Hyaline membranes were also present in two cases. The Gram stains of all three cases showed numerous clusters of Gram positive and Gram negative cocci. Most of these cocci were extracellular, but a few intracellular cocci could also be seen (Fig. 1).

The anti-group B Streptococcus monoclonal antibody clearly showed both extracellular and intracellular cocci. The extracellular cocci were seen as single organisms lying in tissue spaces. Intracellular cocci were seen within phagocytic cells in greater numbers than had been evident with the Gram stained preparations.

In addition to the discrete staining of intracellular cocci, abundant diffuse staining could be seen in the cytoplasm of some phagocytic cells (Fig. 2). Control sections processed in parallel without the monoclonal antibody confirmed that there was no residual endogenous peroxidase activity in these phagocytic cells.

The staining results obtained with the polyclonal antibody were qualitatively inferior compared with

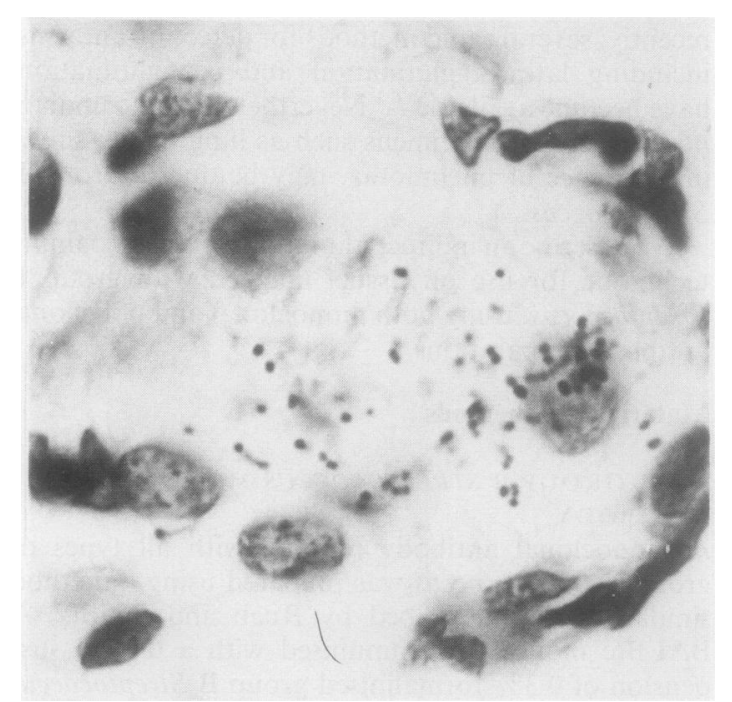

Fig. 1 Section of lung showing extracellular and intracellular Gram positive cocci. Organisms appear lanceolate and some have haloes suggesting the presence of capsules. (Gram stain.) $\times 1000$. 


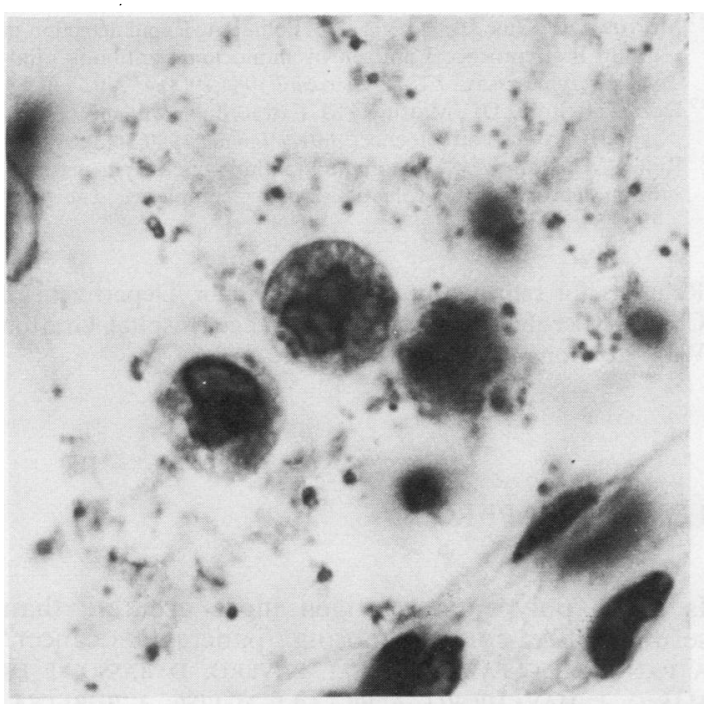

Fig. 2 Section of lung stained with anti-group B Streptococcus monoclonal antibody showing discrete cocci and diffuse staining of cytoplasm of phagocytic cells. Some organisms appear as a ring, indicating specific staining of bacterial cell wall. (Immunoperoxidase.) $\times 1000$.

the anti-group B Streptococcus monoclonal antibody, although both extracellular and intracellular cocci could be seen.

Immunoperoxidase staining with the monoclonal antibody on the lungs affected by organisms other than group B Streptococcus did not show staining of any importance.

\section{Discussion}

Infections with group B Streptococcus are an important cause of neonatal morbidity and mortality. Although rapid methods for the detection of group B Streptococcus antigen in body fluids have been well documented, in cases reaching postmortem examination, differentiating group B Streptococcus pneumonia from other bacteriological causes can be difficult because of the similar appearances under light microscopy. Although bacteria can usually be shown by the Gram stain, exact identification is not possible, and non-viable organisms may appear Gram negative.

We have described the use of an anti-group B Streptococcus monoclonal antibody in an indirect immunoperoxidase technique that permits the detection and identification of all types of group B Streptococcus in formalin fixed paraffin embedded tissues. The specific detection of group B Streptococcus in formalin fixed sections should facilitate investigations into the role of this organism in neonatal sepsis.
The superiority of monoclonal antibody over polyclonal antisera with immunohistochemical staining has been well described. ${ }^{10}$ The indirect immunoperoxidase technique with the monoclonal antibody seems to be more sensitive for detecting group B Streptococcus than either the Gram stain or the PAP technique with the polyclonal antiserum: organisms will be shown, whether or not the bacteria are viable at the time of fixation.

Both group specific and type specific monoclonal antibodies directed against group B Streptococcus have been described previously. ${ }^{411}$ Type specific monoclonal antibodies may be of use in determining which serotype of group B Streptococcus is present in histological specimens.

Group B Streptococcus in liquid culture produces excess antigen that dissolves into the medium. ${ }^{12}$ The diffuse staining seen in the cytoplasm of many phagocytic cells may represent aggregations of carbohydrate antigen formed in vivo and subsequently taken up by these cells from the extracellular fluid. Alternatively, these aggregations may be the degraded remains of phagocytosed, killed group B Streptococcus. Staining of an intracytoplasmic bacterial antigen has been shown previously, using an antibody directed against Mycobacterium sp. ${ }^{13}$

We thank Dr DH Crawford, virology department, Royal Postgraduate Medical School, Hammersmith Hospital, for her help in developing the monoclonal antibody; Professor ER Huehns, haematology department, University College Hospital Medical School, for the use of his laboratory; and the Streptococcus grouping laboratory, Public Health Laboratory Service, Colindale, for typing the clinical isolates of group B Streptococcus.

\section{References}

' Lannering B, Larson LE, Rojas J, Stahlman MT. Early onset group B streptococcal disease. Seven year experience and clinical scoring system. Acta Paediatr Scand 1983;72:597-602.

${ }^{2}$ Friedman CA, Wender DF, Rawson JE. Rapid diagnosis of group B streptococcal infection utilising a commercially available latex agglutination assay. Pediatrics 1984;73(1):27-30.

${ }^{3}$ Leland DS, Lachapelle RC, Wlodarski FM. Method for rapid detection of group B streptococci by coagglutination. J Clin Microbiol 1978;7(4):323-6.

${ }^{4}$ Ruch FE, Smith L. Monoclonal antibody to streptococcal group B carbohydrate: applications in latex agglutination and immunoprecipitation assays. J Clin Microbiol 1982;16(1):145-52.

${ }^{5}$ Lancefield RC, McCarthy M, Everly WN. Multiple mouseprotective antibodies directed against group B streptococci. $J$ Exp Med 1975;142:165-79.

${ }^{6} \mathrm{Kohler}$ G, Milstein C. Continuous cultures of fused cells secreting antibody of predefined specificity. Nature 1975;256:495-7.

${ }^{7}$ Riser E, Noone P, Poulton TA. A new serotyping method for 
Klebsiella sp: development of the technique. J Clin Pathol 1976;29:296-304.

${ }^{8}$ Stein H, Bonk A, Toksdorf G, Lennert K, Rodt K, Gerdes J. Immunohistological analyses of the organisation of normal lymphoid tissue and non-Hodgkin's lymphomas. J Histochem Cytochem 1980;28:746-60.

${ }^{9}$ Mepham BL, Frater W, Mitchell BS. The use of proteolytic enzymes to improve immunoglobulin staining by the PAP technique. Histochem $J$ 1979;11:345-57.

${ }^{10}$ Gatter KC, Falini B, Mason DY. The use of monoclonal antibodies in histopathological diagnosis. In: Anthony PP, MacSween RNM, eds. Recent advances in Histopathology. Number 12. Edinburgh: Churchill Livingstone, 1984:38-9.
${ }^{11}$ Morrow DL, Kline JB, Douglas SD, Polin RA. Rapid detection of group B streptococcal antigen by monoclonal antibody sandwich enzyme assay. J Clin Microbiol 1984;19(4):457-9.

${ }^{12}$ Doran TI, Straus DC, Mattingly SJ. Extracellular antigens of serotype III group B streptococci. Infect Immun 1980;30(3):890-3.

${ }^{13}$ Ridley MJ, Ridley DS. The immunopathology of erythema nodosum leprosum: the role of vascular complexes. Lepr Rev 1983;54:95-107.

Requests for reprints to: Dr RG Feldman, Department of Clinical Microbiology, University College Hospital, Grafton Way, London WCIE 6AU, England.

\section{The January 1986 issue}

\section{THE JANUARY 1986 ISSUE CONTAINS THE FOLLOWING PAPERS}

\section{Review article}

Eosinophilic infiltrates of the gastrointestinal tract AJ BLACKSHAW, DA LEVISON

Immunophenotype analysis of malignant histiocytosis of the intestine DM SALTER, AS KRAJEWSKI, AE DEWAR

Malignant histiocytosis complicating rheumatoid arthritis: report of four cases AS JACK, BF BOYCE, FD LEE

Cervical glandular atypia associated with squamous intraepithelial neoplasia: a premalignant lesion? LJR BROWN, M WELLS

Does ovarian sex cord tumour with annular tubules produce progesterone? J DOLAN, AH AL-TIMIMI, SM RICHARDS, JB JEFFS, GC MASON, DB SMITH, PS HASLETON

New concept in diagnostic endometrial cytology: diagnostic criteria based on composition and architecture of large tissue fragments in smears ELSA SKAARLAND

Cryostat section assay of oestrogen and progesterone receptors in meningiomas: a clinicopathological study JW IRONSIDE, RDE BATTERSBY, VICTORIA JM DANGERFIELD, MA PARSONS, WR TIMPERLEY, JCE UNDERWOOD

Study of childhood renal tumours using antisera to fibronectin, laminin, and epithelial membrane antigen $\mathrm{S}$ KUMAR, $\mathrm{T}$ CARR, HB MARSDEN, MC CALABUIG-CRESPO

Alpha-1-antitrypsin and the liver: a routine immunohistological screen JM THEAKER, KA FLEMING

Hepatic vein lesions in alcoholic liver disease: retrospective biopsy and necropsy study AD BURT, RNM MacSWEEN

Clinical pathology of acute necrotising pancreatitis I NORDBACK, $K$ LAUSLAHTI
Is tissue polypeptide antigen more accurate than serum CEA for diagnosing pancreatic cancer? A PANUCCI, C FABRIS, G DEL FAVERO, D BASSO, F DI MARIO, L MARCHIORO, A PICCOLI, M LISE, A BURLINA, R NACCARATO

Study of postoperative chest infections with particular emphasis on those caused by Haemophilus influenzae GM TEBBUTT

Chronic respiratory disease in premature infants caused by Chlamydia trachomatis $\mathrm{K}$ NUMAZAKI, S CHIBA, K KOGAWA, M UMETSU, H MOTOYA, T NAKAO Evaluation of lysis filtration as an adjunct to conventional blood culture RACHAEL CHAN, ROSEMARY MUNRO, P TOMLINSON

Survival of Gram positive anaerobic cocci on swabs and their isolation from the mouth and vagina GILLIAN LF SMITH, CG CUMMING, PW ROSS

Correlations between nuclear morphology and bundles of cytoplasmic fibrils in 50 cases of acute myeloid leukaemia EC PEARSON

Racial differences in red cell indices D ISAACS, DG ALTMAN, HV VALMAN

Guidelines on authorship

\section{Technical methods}

Staining of mycobacterium leprae in epoxy resin sections KE BRASSIL

Detection of Campylobacter pyloridis in gastric mucosa by phase contrast microscopy KEITEE J PINKARD, B HARRISON, JA CAPSTICK, G MEDLEY, JR LAMBERT

\section{Letters to the Editor}

Book reviews

Notices

Copies are still available and may be obtained from the PUBLISHING MANAGER BRITISH MEDICAL ASSOCIATION, TAVISTOCK SQUARE, LONDON WCl 9JR, price $£ 5.00$, including postage. 